\title{
LETTER
}

\section{Circulating microRNAs: promising breast cancer biomarkers - authors' response}

\author{
Carina Roth', Brigitte Rack², Volkmar Müller ${ }^{3}$, Wolfgang Janni', Klaus Pantel' and Heidi Schwarzenbach¹ \\ See related research by Roth et al., http://breast-cancer-research.com/content/12/6/R90 and related letter by Heneghan et al., \\ http://breast-cancer-research.com/content/13/1/402
}

We thank Heneghan and colleagues for their interest [1] in our article [2].

We do not claim our article to be the first evidence that circulating microRNAs (miRNAs) have potential as breast cancer biomarkers, and we acknowledge that other groups such as theirs are working on this exciting new area (for example, [3]). However, we think that our data on the association with breast tumor progression are novel.

The finding that total RNA levels were higher in M0 patients than in controls and M1 breast cancer patients cannot exclusively reflect the quality of our used RNA extraction technique because the difference in the concentrations was significant, and we used the same technique for all groups. When we quantified the RNA concentrations using the mirVana PARIS kit (Ambion) and the Trizol $^{\circledR}$ extraction (Invitrogen), we found the RNA amounts differed considerably, but the relative changes in the RNA levels of the different groups showed the same tendency. The fact that whole blood contains higher RNA amounts than serum/plasma is an undisputable matter. However, we intended to measure the amounts of cell-free RNA.

In our article we discussed that the lower total RNA levels in patients with metastatic disease compared to M0 patients might be explained in part by the different tissue sources (for example, primary tumor, circulating tumor cells and mononuclear cells) from which the bulk of RNA in blood may come. The claim that total RNA concentration indicated tumor progression alludes to the higher total RNA levels detected in the more advanced tumor stages within the M0 subgroup.

\footnotetext{
*Correspondence: hschwarz@uke.uni-hamburg.de

'Institute of Tumor Biology, University Medical Center Hamburg-Eppendorf, 20246 Hamburg, Germany

Full list of author information is available at the end of the article
}

We selected our miRNA panel from a large number of existing miRNAs because these miRNAs target mRNAs crucial in breast cancer progression (for example, epithelial-mesenchymal transition). Certainly, there are other miRNAs strongly associated with breast cancer.

We agree that the pre-operative analysis of blood should be more informative for cancer detection, whereas the post-operative analysis might be more valuable to estimate tumor progression. Our small pilot study on sera from 10 patients revealed similar levels before and about 4 weeks after surgery $(P=0.375)$; however, this aspect needs to be revisited with a larger cohort of patients.

\section{Abbreviations \\ miRNA, microRNA.}

\section{Competing interests}

The authors declare that they have no competing interests.

\section{Author details}

IInstitute of Tumor Biology, University Medical Center Hamburg-Eppendorf, 20246 Hamburg, Germany. ${ }^{2}$ First Department of Obstetrics and Gynecology, Ludwig Maximilians University of Munich, 80539 Munich, Germany. ${ }^{3} \mathrm{Clinic}$ of Gynecology, University Medical Center Hamburg-Eppendorf, 20246 Hamburg, Germany. ${ }^{4}$ Clinic of Gynecology, Heinrich Heine University, 40225 Düsseldorf, Germany.

\section{Published: 4 February 2011}

\section{References}

1. Heneghan HM, Miller N, Kerin MJ: Circulating microRNAs: promising breast cancer biomarkers. Breast Cancer Res 2011, 13:402.

2. Roth C, Rack B, Muller V, Janni W, Pantel K, Schwarzenbach H: Circulating microRNAs as blood-based markers for patients with primary and metastatic breast cancer. Breast Cancer Res 2010, 12:R90.

3. Heneghan HM, Miller N, Lowery AJ, Sweeney KJ, Newell J, Kerin MJ: Circulating microRNAs as novel minimally invasive biomarkers for breast cancer. Ann Surg 2010, 251:499-505.

doi: $10.1186 /$ bcr2812

Cite this article as: Roth $C_{\text {, et al: }}$ Circulating microRNAs: promising breast cancer biomarkers - authors' response. Breast Cancer Research 2011, 13:403. 